\title{
Corrosion Inhibition by Beet Root Extract
}

\author{
J. Arockia Selvi, ${ }^{1}$ Susai Rajendran, ${ }^{1, *}$ V. Ganga Sri, ${ }^{1}$ \\ A. John Amalraj, ${ }^{2}$ B. Narayanasamy ${ }^{3}$ \\ ${ }^{1}$ Corrosion Research Centre, Department of Chemistry GTN Arts College, \\ Dindigul - 624005 - Tamil Nadu, India \\ ${ }^{2}$ Department of Chemistry, Loyola College, Chennai, Tamil Nadu, India \\ ${ }^{3}$ Department of Chemistry, Thiagarajar College of Engineering, Madurai, \\ Tamil Nadu, India
}

Received 28 June 2008; accepted 30 September 2008

\begin{abstract}
The inhibition efficiency (IE) of an aqueous extract of beet root (BR) in controlling corrosion of carbon steel in well water in the absence and presence of $\mathrm{Zn}^{2+}$ has been evaluated by mass loss method. The formulation consisting of $4 \mathrm{~mL}$ of BR extract and $50 \mathrm{ppm} \mathrm{Zn}^{2+}$ offers $98 \%$ inhibition efficiency to carbon steel immersed in well water. A synergistic effect exists between BR extract and $\mathrm{Zn}^{2+}$. Addition of N-Cetyl-N,N,N trimethylammonium bromide (CTAB) does not change the excellent inhibition efficiency of the $\mathrm{BR}-\mathrm{Zn}^{2+}$ system. The $\mathrm{BR}-\mathrm{Zn}^{2+}$ system shows excellent IE up to 7 days. Polarization study reveals that this formulation controls the cathodic reaction predominantly. AC impedance spectra reveal that a protective film is formed on the metal surface. FTIR spectra reveal that the protective film consists of $\mathrm{Fe}^{2+}$ - betanin complex and $\mathrm{Zn}(\mathrm{OH})_{2}$. The film is found to be UV - fluorescent.
\end{abstract}

Keywords: carbon steel, corrosion inhibition, plant extract, beet root, beta vulgaris.

\section{Introduction}

Environmental friendly inhibitors have attracted several researchers. Natural products are nontoxic, biodegradable and readily available. They have been used widely as inhibitors. Natural products such as caffeine $[1,2]$ have been used as inhibitors. Corrosion inhibition of steel by plant extracts in acidic media has been reported [3, 4]. Scale inhibiting nature of plant extracts for various kinds of metals are summarized briefly [5]. Natural compounds as corrosion inhibitors for industrial cooling systems have been studied [6]. Aqueous extract of Rosemary leaves [7], Zenthoxylum - alatum [8] and Lawsonia [9] have been used to inhibit

\footnotetext{
* Corresponding author. E-mail address: srmjoany@ sify.com
} 
corrosion of metals. Corrosion inhibition of iron in hydrochloric acid solutions by naturally occurring Henna has been investigated [10]. An aqueous extract of plant material rhizome (Curcuma Longa L) powder has been used as a corrosion inhibitor for carbon steel [11]. Aqueous extracts of Onion [12], Androgaphis panizulata [13] have been used as corrosion inhibitors. Inhibitive action of Carcia papaya extracts on the corrosion of mild steel in acidic media and their adsorption characteristics have been studied [14]. Azadirachta indica in acid solution has good corrosion inhibitive property [15]. Corrosion inhibition of carbon steel in low chloride media by an aqueous extract of Hibiscus rosasinensis Linn has been evaluated by mass-loss method and electrochemical studies [16]. Investigation of natural inhibitors is particularly interesting because they are non-expensive, ecologically friendly/ acceptable and possess no threat to the environment. The present work is undertaken:

(i) to evaluate the inhibition efficiency (IE) of an aqueous extract of beet root (BR) in controlling the corrosion of carbon steel in well water, in the absence and presence of $\mathrm{Zn}^{2+}$;

(ii) to examine the influence of N-cetyl - N,N,N-trimethylammonium bromide $(\mathrm{CTAB})$, a biocide, and duration of immersion on the IE of the $\mathrm{BR}-\mathrm{Zn}^{2+}$ system;

(iii) to analyze the protective film formed on the carbon steel by FTIR spectra and fluorescence spectra;

(iv) to understand the mechanistic aspects of corrosion inhibition by potentiodynamic polarization studies and $\mathrm{AC}$ impedance analysis; and

(v) to propose a suitable mechanism for corrosion inhibition.

\section{Experimental}

\section{Preparation of plant extract}

An aqueous extract of beet root was prepared by grinding $10 \mathrm{~g}$ of beet root with double distilled water, filtering the suspending impurities, and making up to 100 $\mathrm{mL}$. The extract was used as corrosion inhibitor in the present study.

\section{Preparation of specimens}

Carbon steel specimens $(0.0267 \% \mathrm{~S}, 0.06 \% \mathrm{P}, 0.4 \% \mathrm{Mn}, 0.1 \% \mathrm{C}$ and the rest iron) of dimensions $1.0 \mathrm{~cm} \times 4.0 \mathrm{~cm} \times 0.2 \mathrm{~cm}$ were polished to a mirror finish and degreased with trichloroethylene.

\section{Mass-loss method}

Relevant data on the well water used in this study are given in Table I. Carbon steel specimens in triplicate were immersed in $100 \mathrm{~mL}$ of the solutions containing various concentrations of the inhibitor in the presence and absence of $\mathrm{Zn}^{2+}$ for one day. The weight of the specimens before and after immersion was determined using Shimadzu balance, model AY 62. The corrosion products were cleansed with Clarke's solution [17]. The inhibition efficiency (I.E.) was then calculated using the equation 


$$
\mathrm{I} . \mathrm{E}=100\left[1-\left(\mathrm{W}_{2} / \mathrm{W}_{1}\right)\right] \%
$$

where $\mathrm{W}_{1}$ and $\mathrm{W}_{2}$ are the corrosion rates in the absence and presence of the inhibitor, respectively.

Table 1. Parameters of well water.

\begin{tabular}{|l|l|}
\hline Parameter & \multicolumn{1}{|c|}{ Value } \\
\hline pH & 8.38 \\
Conductivity & $3110 \mu \mathrm{mhos} / \mathrm{cm}$ \\
TDS & $2013 \mathrm{ppm}$ \\
Chloride & $665 \mathrm{ppm}$ \\
Sulphate & $14 \mathrm{ppm}$ \\
Total hardness & $1100 \mathrm{ppm}$ \\
\hline
\end{tabular}

\section{Surface examination}

The carbon steel specimens were immersed in various test solutions for a period of one day, taken out and dried. The nature of the film formed on the surface of metal specimens was analyzed by FTIR spectroscopic study.

\section{FTIR spectra}

FTIR spectra were recorded in a Perkin - Elmer 1600 spectrophotometer. The film was carefully removed, mixed thoroughly with $\mathrm{KBr}$ made in to pellets and FTIR spectra were recorded.

\section{Fluorescence spectra}

These spectra were recorded in a Hitachi F - 4500 fluorescence spectrophotometer.

\section{Potentiodynamic polarization}

Polarization studies were carried out in an $\mathrm{H} \& \mathrm{CH}$ electrochemical work station impedance analyzer model CHI 660A. A three electrode cell assembly was used. The working electrode was carbon steel. A saturated calomel electrode (SCE) was used as the reference electrode and a rectangular platinum foil was used as the counter electrode.

\section{AC impedance measurements}

The instrument used for polarization was also used for AC impedance study. The cell set up was the same as that used for polarization measurements. The real part and imaginary part of the cell impedance were measured in ohms at various frequencies. The values of charge transfer resistance, $\mathrm{R}_{t}$, and the double layer capacitance, $\mathrm{C}_{\mathrm{dl}}$, were calculated. 


\section{Results and discussion}

\section{Analysis of results of mass loss method}

The corrosion rate (CR) of carbon steel immersed in well water (whose composition is given in Table 1) in the absence and presence of inhibitor systems are given in Tables 2-4. The inhibition efficiencies (IE) are also given in these Tables.

It is seen from Table 2 that the aqueous extract of beet root (BR) is not a good inhibitor to carbon steel in well water. $2 \mathrm{~mL}$ of BR show only $42 \%$ IE. As concentration BR increases, IE slowly decreases. That is, at higher concentrations, BR accelerates corrosion. It favours dissolution of carbon steel in well water.

Table 2. Corrosion rate (CR) of carbon steel immersed in well water, in the absence and presence of inhibitors, and the inhibition efficiency (IE) obtained by mass loss method. Immersion period: one day; inhibitor: $10 \%$ aqueous extract of beet root (BR) $+\mathrm{Zn}^{2+}$.

\begin{tabular}{|c|c|c|c|c|c|c|}
\hline \multirow{3}{*}{$\begin{array}{c}\text { BR } \\
\text { extract } \\
\text { mL }\end{array}$} & \multicolumn{6}{|c|}{$\mathrm{Zn}^{2+}$} \\
\hline & \multicolumn{2}{|c|}{$\begin{array}{c}\mathbf{0} \\
(\mathbf{p p m})\end{array}$} & \multicolumn{2}{|c|}{$\begin{array}{c}25 \\
(\mathrm{ppm})\end{array}$} & \multicolumn{2}{|c|}{$\begin{array}{c}50 \\
(\mathbf{p p m})\end{array}$} \\
\hline & $\begin{array}{l}\text { CR } \\
\text { (mdd) }\end{array}$ & $\begin{array}{l}\text { IE } \\
\%\end{array}$ & $\begin{array}{l}\text { CR } \\
\text { (mdd) }\end{array}$ & $\begin{array}{l}\text { IE } \\
\%\end{array}$ & $\begin{array}{l}\text { CR } \\
\text { (mdd) }\end{array}$ & $\begin{array}{l}\text { IE } \\
\%\end{array}$ \\
\hline 0 & 38.18 & - & 38.18 & -- & 38.18 & -- \\
\hline 0 & - & - & 35.12 & 8 & 29.8 & 22 \\
\hline 2 & 22.14 & 42 & 0.76 & 98 & 0.76 & 98 \\
\hline 4 & 52.31 & -37 & 1.52 & 96 & 0.77 & 98 \\
\hline 6 & 57.27 & -50 & 1.91 & 95 & 0.78 & 98 \\
\hline 8 & 62.62 & -64 & 3.83 & 90 & 0.76 & 98 \\
\hline
\end{tabular}

\section{Influence of $\mathrm{Zn}^{2+}$ on the inhibition efficiency of $\mathrm{BR}$}

The influence of $\mathrm{Zn}^{2+}$ on the IE of BR is given in Table 2. In the presence of $\mathrm{Zn}^{2+}(25 \mathrm{ppm}, 50 \mathrm{ppm})$ excellent inhibitive property is shown by BR. A synergistic effect exists between $\mathrm{BR}$ and $\mathrm{Zn}^{2+}$. For example, $4 \mathrm{~mL}$ of $\mathrm{BR}$ accelerate corrosion of carbon steel (IE $=-37 \%$ ); $50 \mathrm{ppm}$ of $\mathrm{Zn}^{2+}$ have $22 \%$ IE. But their combination has $98 \%$. This suggests that a synergistic effect exists between $\mathrm{BR}$ and $\mathrm{Zn}^{2+}$.

Table 3. Influence of CTAB on IE of beet root extract (BR) $(4 \mathrm{~mL})-\mathrm{Zn}^{2+}(50 \mathrm{ppm})$.

\begin{tabular}{|c|c|c|c|c|}
\hline $\begin{array}{c}\text { BR } \\
\text { extract } \\
\text { mL }\end{array}$ & $\begin{array}{c}\mathbf{Z n}^{2+} \\
\mathbf{p p m}\end{array}$ & $\begin{array}{c}\mathbf{C T A B} \\
\mathbf{p p m}\end{array}$ & $\begin{array}{c}\mathbf{C R} \\
\mathbf{m d d}\end{array}$ & $\begin{array}{c}\mathbf{I E} \\
\mathbf{\%}\end{array}$ \\
\hline 0 & 0 & 0 & 38.18 & -- \\
4 & 50 & 0 & 0.78 & 98 \\
4 & 50 & 50 & 0.77 & 98 \\
4 & 50 & 100 & 0.76 & 98 \\
4 & 50 & 150 & 0.78 & 98 \\
4 & 50 & 200 & 0.77 & 98 \\
\hline
\end{tabular}


Table 4. Influence of duration of immersion on IE of BR (4 mL) - $\mathrm{Zn}^{2+}(50 \mathrm{ppm})$.

\begin{tabular}{|l|c|c|c|c|}
\hline \multicolumn{1}{|c|}{ Immersion period (days) } & $\mathbf{1}$ & $\mathbf{3}$ & $\mathbf{5}$ & $\mathbf{7}$ \\
\hline $\begin{array}{l}\mathrm{CR}, \mathrm{mdd} \\
\text { System: } \mathrm{BR}(0 \mathrm{~mL})+\mathrm{Zn}^{2+} \\
(0 \mathrm{ppm})+\text { well water }\end{array}$ & 38.18 & 19.1 & 17.8 & 16.1 \\
\hline $\begin{array}{l}\text { CR, mdd } \\
\text { System: well water + BR (4 } \\
\mathrm{mL})+\mathrm{Zn}^{2+}(50 \mathrm{ppm})\end{array}$ & 0.76 & 0.38 & 0.36 & 0.81 \\
\hline $\mathrm{IE}(\%)$ & 98 & 98 & 98 & 95 \\
\hline
\end{tabular}

Influence of $N$-cetyl $N, N, N$ - trimethylammonium bromide (CTAB) on the inhibition efficiency of $B R(4 \mathrm{~mL})-\mathrm{Zn}^{2+}(50 \mathrm{ppm})$ system

The influence of CTAB on the inhibition efficiency of BR $(4 \mathrm{~mL})-\mathrm{Zn}^{2+}(50$ ppm) system is given in Table 3. It is interesting to find that the IE of the BR $\mathrm{Zn}^{2+}$ system is not changed by the addition of CTAB. CTAB is a biocide. It can control the corrosion caused by bacteria [18]. The present study reveals that the formulation consisting of $\mathrm{BR}, \mathrm{Zn}^{2+}$ and $\mathrm{CTAB}$ has excellent corrosion inhibition efficiency. It is expected that this formulation will have excellent biocidal efficiency also. Hence this formulation may be used in cooling water system.

\section{Influence of duration of immersion on the IE of BR (4 mL) - $\mathrm{Zn}^{2+}(50 \mathrm{ppm})$} system

The influence of duration of immersion on the IE of BR $(4 \mathrm{~mL})-\mathrm{Zn}^{2+}$ ppm) system is given in Table 4. It is found that the formulation consisting of $\mathrm{BR}$ and $\mathrm{Zn}^{2+}$ shows good IE even up to 7 days. The protective film is able to withstand the attack of the corrosive ions such as chloride ion (665 ppm) present in the well water.

\section{Analysis of polarization curves}

The potentiodynamic polarization curves of carbon steel immersed in well water in the absence and presence of inhibitors are shown in Fig. 1. The corrosion parameters are given in Table 5. When carbon steel is immersed in well water the corrosion potential is $-549 \mathrm{mV}$ vs. SCE (Saturated Calomel Electrode). The corrosion current is $3.981 \times 10^{-5} \mathrm{~A} / \mathrm{cm}^{2}$. When $4 \mathrm{~mL}$ of $\mathrm{BR}$ and $50 \mathrm{ppm}$ of $\mathrm{Zn}^{2+}$ are added to the above system, the corrosion potential shifts to the cathodic side (-572 $\mathrm{mV}$ vs. SCE). This suggests that this formulation controls the cathodic reaction predominantly. In the presence of this inhibitor system, the corrosion current decreases from $3.981 \times 10^{-5} \mathrm{~A} / \mathrm{cm}^{2}$ to $3.162 \times 10^{-5} \mathrm{~A} / \mathrm{cm}^{2}$. This suggests the inhibitive nature of this inhibitor system. 


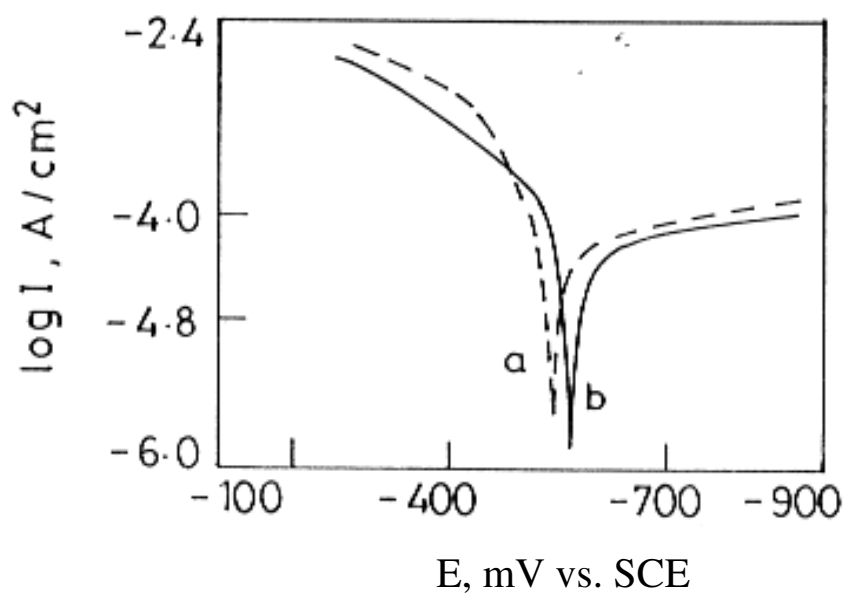

Figure 1. Polarization curves of carbon steel immersed in various solutions. a) Well water. b) Well water $+4 \mathrm{~mL} \mathrm{BR}+50 \mathrm{ppm}$ of $\mathrm{Zn}^{2+}$.

Table 5. Corrosion parameters of carbon steel immersed in well water in the absence and presence of inhibitors. Inhibitor system: $\mathrm{BR}+\mathrm{Zn}^{2+}$.

\begin{tabular}{|c|c|c|c|c|c|}
\hline $\begin{array}{c}\text { BR } \\
\mathbf{m L}\end{array}$ & $\begin{array}{c}\mathbf{Z n}^{\mathbf{2 +}} \\
\mathbf{p p m}\end{array}$ & $\begin{array}{c}\mathbf{E}_{\text {corr }} \\
\mathbf{m V} \mathbf{~ v s . ~ S C E}\end{array}$ & $\begin{array}{c}\mathbf{b}_{\mathbf{a}} \\
\mathbf{m V}\end{array}$ & $\begin{array}{c}\mathbf{b}_{\mathbf{c}} \\
\mathbf{m V}\end{array}$ & $\begin{array}{c}\mathbf{I}_{\text {corr }} \\
\mathbf{A} / \mathbf{c m}^{2}\end{array}$ \\
\hline 0 & 0 & -549 & 76 & 262 & $3.981 \times 10^{-5}$ \\
4 & 50 & -572 & 119 & 71 & $3.162 \times 10^{-5}$ \\
\hline
\end{tabular}

\section{Analysis of AC impedance spectra}

The AC impedance spectra of carbon steel immersed in well water, in the absence and presence of inhibitors are shown in Fig. 2. The AC impedance parameters such as charge transfer resistance $\left(\mathrm{R}_{\mathrm{t}}\right)$ and double layer capacitance $\left(\mathrm{C}_{\mathrm{dl}}\right)$ are given in Table 6 . When carbon steel is immersed in well water, the charge transfer resistance $R_{t}$ is $60.06 \mathrm{ohm} . \mathrm{cm}^{2}$; the double layer capacitance $C_{\mathrm{dl}}$ is $3.27 \times 10^{-8} \mu \mathrm{F} / \mathrm{cm}^{2}$. When the formulation consisting of $\mathrm{BR}$ and $\mathrm{Zn}^{2+}$ is added, the $\mathrm{R}_{\mathrm{t}}$ value increases and $\mathrm{C}_{\mathrm{dl}}$ value decreases. This confirms that a protective film is formed on the metal surface. This decreases the corrosion rate of carbon steel and increases the inhibition efficiency.

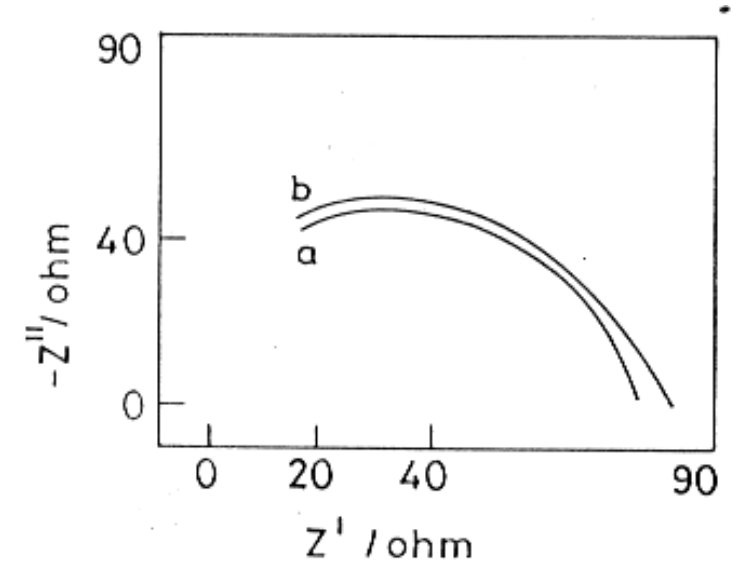

Figure 2. AC impedance spectra of carbon steel immersed in various solutions. a) Well water. b) Well water $+4 \mathrm{~mL} \mathrm{BR}+50 \mathrm{ppm}$ of $\mathrm{Zn}^{2+}$. 
Table 6. AC impedance parameters of carbon steel immersed in well water in the absence and presence of inhibitors. Inhibitor system: $\mathrm{BR}+\mathrm{Zn}^{2+}$.

\begin{tabular}{|c|c|c|c|}
\hline $\begin{array}{c}\mathbf{B R} \\
\mathbf{m L}\end{array}$ & $\begin{array}{c}\mathbf{Z n}^{2+} \\
\mathbf{p p m}\end{array}$ & $\begin{array}{c}\mathbf{R}_{\mathbf{t}} \\
\mathbf{O h m . \mathbf { c m } ^ { 2 }}\end{array}$ & $\begin{array}{c}\mathbf{C}_{\mathbf{d l}} \\
\boldsymbol{\mu} \mathbf{F} / \mathbf{c m}^{2}\end{array}$ \\
\hline 0 & 0 & 60.06 & $3.27 \times 10^{-8}$ \\
4 & 50 & 68.22 & $2.88 \times 10^{-8}$ \\
\hline
\end{tabular}

\section{Comparison of results of mass loss method and electrochemical studies}

In the present work mass loss study was carried out keeping the duration of immersion as 24 hours. It the electrochemical studies such as polarization and AC impedance, the instantaneous corrosion process is studied.

The mass loss study shows a tremendous difference between the corrosion rate of the blank system (well water only) and the inhibitor system (well water + BR 4 $\left.\mathrm{mL}+\mathrm{Zn}^{2+} 50 \mathrm{ppm}\right) ; 98 \%$ IE is obtained. In polarization study the corrosion current is decreased only to a small extent (from $3.981 \times 10^{-5} \mathrm{~A} / \mathrm{cm}^{2}$ to $3.162 \times 10^{-5}$ $\mathrm{A} / \mathrm{cm}^{2}$ ). In $\mathrm{AC}$ impedance study the increase in $\mathrm{R}_{\mathrm{t}}$ value (from 60.06 to 68.22 ohm. $\left.\mathrm{cm}^{2}\right)$ and the decrease in $\mathrm{C}_{\mathrm{dl}}$ value $\left(3.27 \times 10^{-8}\right.$ to $\left.2.88 \times 10^{-8} \mu \mathrm{F} / \mathrm{cm}^{2}\right)$ are very small. This is attributed to the various ions such as $\mathrm{Ca}^{2+}$ and $\mathrm{Mg}^{2+}$, apart from chloride ion and sulphate ion. The various ions present in well water instantaneously form a protective film on the metal surface. But this film is broken in due course.

\section{Analysis of FTIR spectra}

The active principle in an aqueous extract of beet root is betanin. The red colour of the extract is due to betanin [19].

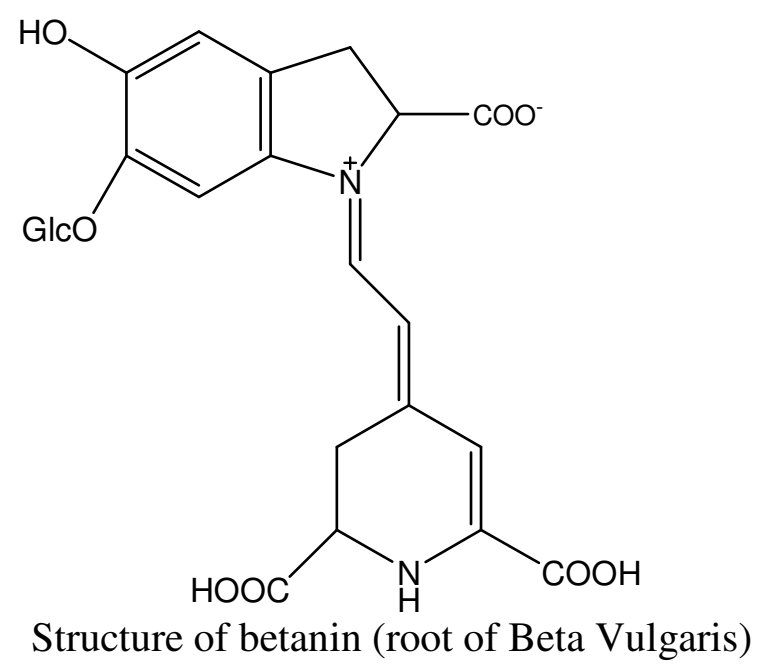

A few drops of an aqueous extract of beet root was dried on a glass plate. A solid mass was obtained. Its FTIR spectrum is shown Fig. 3a. The $\mathrm{C}=\mathrm{O}$ stretching frequency appears at $1587 \mathrm{~cm}^{-1}$. The $\mathrm{OH}$ stretching frequency appears at $3693 \mathrm{~cm}^{-1}$. The $\mathrm{C}-\mathrm{N}$ stretching frequency appears at $1248 \mathrm{~cm}^{-1}$. The band due to conjugated double bonds appears at $3788 \mathrm{~cm}^{-1}$. The asymmetric $\mathrm{C}-\mathrm{O}-\mathrm{C}$ 
stretching frequency appears at $1248 \mathrm{~cm}^{-1}$. The symmetric C-O-C stretching frequency appears at $1068 \mathrm{~cm}^{-1}$. Thus the structure of betanin is confirmed by FTIR spectra [20].

The FTIR spectrum of complex prepared by mixing BR extract and $\mathrm{Fe}^{2+}$ is shown in Fig 3b. The $\mathrm{C}=\mathrm{O}$ stretching frequency shifts from $1587 \mathrm{~cm}^{-1}$ to $1595 \mathrm{~cm}^{-1}$. The $\mathrm{OH}$ stretching frequency shifts from $3693 \mathrm{~cm}^{-1}$ to $3698 \mathrm{~cm}^{-1}$. The C-N stretching frequency shifts from $1248 \mathrm{~cm}^{-1}$ to $1242 \mathrm{~cm}^{-1}$. The band due to conjugated double bonds shifts from $3788 \mathrm{~cm}^{-1}$ to $3794 \mathrm{~cm}^{-1}$. The asymmetric C$\mathrm{O}-\mathrm{C}$ stretching frequency shifts from $1248 \mathrm{~cm}^{-1}$ to $1242 \mathrm{~cm}^{-1}$. The symmetric C$\mathrm{O}-\mathrm{C}$ stretching frequency shifts from $1068 \mathrm{~cm}^{-1}$ to $1097 \mathrm{~cm}^{-1}$. These frequency shifts from BR show the formation of complex between $\mathrm{BR}$ and $\mathrm{Fe}^{2+}$ and betanin. The FTIR spectrum of the film formed on the surface of the metal after immersion in the solution containing well water, $4 \mathrm{~mL}$ of BR and $50 \mathrm{ppm}$ of $\mathrm{Zn}^{2+}$ is shown in Fig 3c. The $\mathrm{C}=\mathrm{O}$ stretching frequency shifts from $1587 \mathrm{~cm}^{-1}$ to 1592 $\mathrm{cm}^{-1}$. The $\mathrm{OH}$ stretching frequency shifts from $3693 \mathrm{~cm}^{-1}$ to $3697 \mathrm{~cm}^{-1}$. The C-N stretching frequency shifts from $1248 \mathrm{~cm}^{-1}$ to $1255 \mathrm{~cm}^{-1}$. The band due to conjugated double bond shifts from $3788 \mathrm{~cm}^{-1}$ to $3778 \mathrm{~cm}^{-1}$. The asymmetric C$\mathrm{O}-\mathrm{C}$ stretching frequency shifts from $1248 \mathrm{~cm}^{-1}$ to $1255 \mathrm{~cm}^{-1}$. The symmetric CO-C stretching frequency shifts from $1068 \mathrm{~cm}^{-1}$ to $1066 \mathrm{~cm}^{-1}$. These shifts confirm the formation of $\mathrm{Fe}^{2+}$ - betanin complex on the anodic sites of the metal surface. The peak at $1355 \mathrm{~cm}^{-1}$ is due to $\mathrm{Zn}(\mathrm{OH})_{2}$ formed on the cathodic sites of the metal surface $[21,22]$.

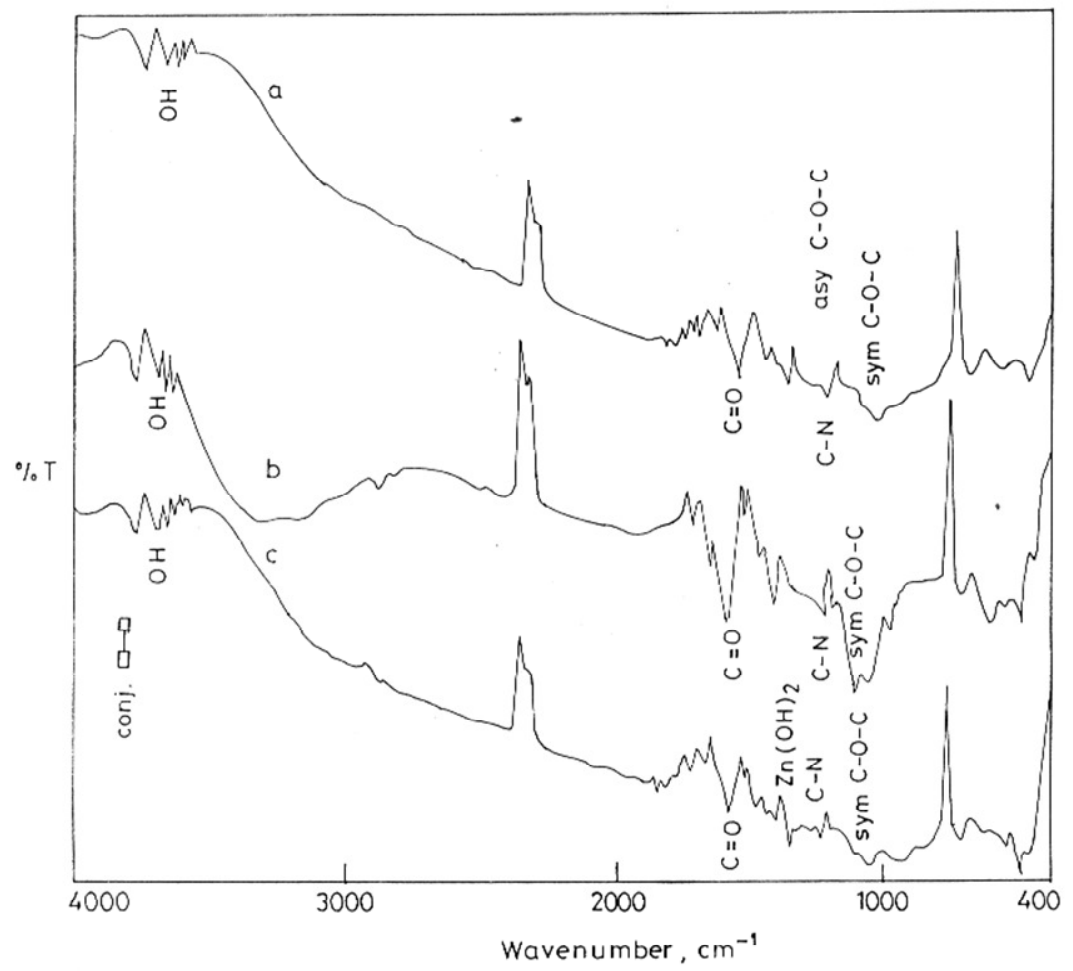

Figure 3. FTIR spectra. a) Solid mass obtained by evaporating the beet root extract (betanin). b) $\mathrm{Fe}^{2+}$ - betanin complex prepared. c) Film formed on surface of the carbon steel specimen after immersion in well water containing $4 \mathrm{~mL}$ of beet root extract and $50 \mathrm{ppm}$ of $\mathrm{Zn}^{2+}$. 


\section{Analysis of fluorescence spectra}

A few drops of the BR extract were dried on a glass plate. A red solid mass was obtained. Its emission spectrum $\left(\lambda_{\mathrm{ex}}=300 \mathrm{~nm}\right)$ is shown in Fig. 4a. Two prominent peaks appeared at $361 \mathrm{~nm}$ and $505 \mathrm{~nm}$.

A few drops of the BR extract were mixed with a few drops of freshly prepared $\mathrm{Fe}^{2+}$ ions (ferrous sulphate). $\mathrm{Fe}^{2+}$ - Betanin complex was formed. It was dried. Its emission spectrum $\left(\lambda_{\mathrm{ex}}=300 \mathrm{~nm}\right)$ is shown in Fig. $4 \mathrm{~b}$. The intensity of the peak at $361 \mathrm{~nm}$ decreased. The peak at $505 \mathrm{~nm}$ disappeared.
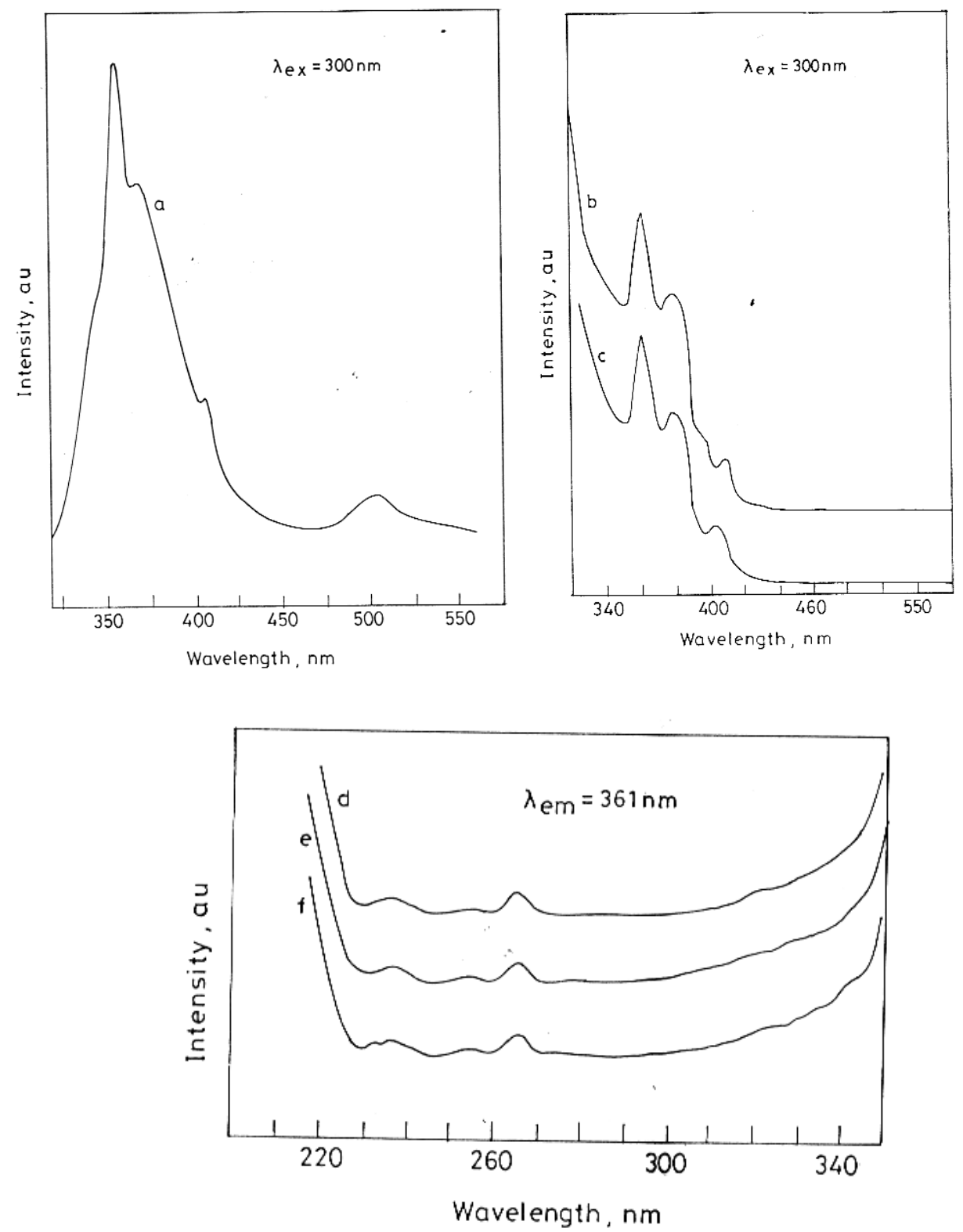

Figure 4. Fluorescence spectra. a) and (d): Emission and excitation spectra of solid mass obtained by evaporating beet root extract (betanin). b) and (e): Emission and excitation spectra of solid $\mathrm{Fe}^{2+}$ - betanin complex prepared. c) and (f): Emission and excitation spectra of film formed on surface of carbon steel specimen after immersion in well water containing $4 \mathrm{~mL}$ of beet root extract and $50 \mathrm{ppm}$ of $\mathrm{Zn}^{2+}$. 
The emission spectrum $\left(\lambda_{\mathrm{ex}}=300 \mathrm{~nm}\right)$ of the film formed on surface of the metal after immersion in the solution containing well water, $4 \mathrm{~mL}$ of BR and $550 \mathrm{ppm}$ of $\mathrm{Zn}^{2+}$, is shown in Fig. 4c. The nature of the spectrum matched well with that of the $\mathrm{Fe}^{2+}$ - betanin complex prepared. This confirmed the presence of $\mathrm{Fe}^{2+}-$ betanin complex formed on the anodic sites of the metal surface.

The excitation spectra $\left(\lambda_{\mathrm{ex}}=361 \mathrm{~nm}\right)$ corresponding to Fig. $4 \mathrm{a}, \mathrm{b}$ and $\mathrm{c}$, are shown in Fig. 4d, e and f, respectively. A peak appeared at $265 \mathrm{~nm}$, in all the cases.

\section{Mechanism of corrosion inhibition}

Mass loss study reveals that the formulation consisting of $4 \mathrm{~mL}$ of $\mathrm{BR}$ and 50 ppm of $\mathrm{Zn}^{2+}$ offers $98 \%$ IE to carbon steel immersed in well water. A synergistic effect exists between $\mathrm{BR}$ and $\mathrm{Zn}^{2+}$. Polarization study reveals that this formulation controls the cathodic reaction predominantly. AC impedance spectra reveal that a protective film is formed on the metal surface. FTIR spectra reveal that the protective film consists of $\mathrm{Fe}^{2+}$ - betanin complex and $\mathrm{Zn}(\mathrm{OH})_{2}$.

In order to explain the above facts in a holistic way, the following mechanism of corrosion inhibition is proposed.

- When the formulation consisting of well water, beet root extract and $\mathrm{Zn}^{2+}$ is prepared, there is formation of $\mathrm{Zn}^{2+}$ - betanin complex in solution.

- When carbon steel is immersed in the solution, the $\mathrm{Zn}^{2+}$ - betanin complex diffuses from the bulk of the solution towards the metal surface.

- On the metal surface, $\mathrm{Zn}^{2+}$ - betanin complex is converted into $\mathrm{Fe}^{2+}$ - betanin complex. $\mathrm{Zn}^{2+}$ is released.

$$
\mathrm{Zn}^{2+}-\text { betanin }+\mathrm{Fe}^{2+} \rightarrow \mathrm{Fe}^{2+}-\text { betanin }+\mathrm{Zn}^{2+}
$$

- The released $\mathrm{Zn}^{2+}$ combines with $\mathrm{OH}$ to form $\mathrm{Zn}(\mathrm{OH})_{2}$ on the cathodic sites.

$$
\mathrm{Zn}^{2+}+2 \mathrm{OH}^{-} \rightarrow \mathrm{Zn}(\mathrm{OH})_{2} \downarrow
$$

- Thus the protective film consists of $\mathrm{Fe}^{2+}$ - betanin complex and $\mathrm{Zn}(\mathrm{OH})_{2}$. This accounts for the synergistic effect.

\section{Conclusions}

The present study leads to the following conclusions:

- the formulation consisting of $4 \mathrm{~mL}$ BR extract and $50 \mathrm{ppm}$ of $\mathrm{Zn}^{2+}$ offers $98 \%$ inhibition efficiency to carbon steel immersed in well water;

- synergistic effect exists between BR extract and $\mathrm{Zn}^{2+}$;

- addition of N-cetyl - N,N,N, - trimethylammonium bromide (CTAB) (a biocide) does not change the excellent inhibition efficiency of the $\mathrm{BR}-\mathrm{Zn}^{2+}$ system;

- BR - $\mathrm{Zn}^{2+}$ system shows excellent IE up to 7 days;

- Polarization study reveals that this formulation controls the cathodic reaction predominantly;

- AC impedance spectra reveal that a protective film is formed on the metal surface;

- FTIR spectra reveal that the protective film consists of $\mathrm{Fe}^{2+}$ - betanin complex and $\mathrm{Zn}(\mathrm{OH})_{2}$; 
- The film is found to be UV - fluorescent.

\section{Acknowledgement}

Authors are thankful to their Managements and University Grants Commission, India, for the help and encouragement.

\section{References}

1. S. Rajendran, S. Vaibhavi, N. Anthony and D.C. Trivedi, Corrosion 59 (2003) 529.

2. S. Rajendran, A. John Amalraj, M. Jasmine Joice, Noreen Anthony, D.C. Trivedi and M. Sundaravadiveelu, Corrosion Reviews 22 (2004) 233.

3. L.R. Chauhan, G. Gunesekaran, Corros. Sci. 49 (2007) 1143.

4. A.M. Abdel-Gaber, B.A. Abd-El-Nabey, I.M. Sidahmed, A.M. El-Zayaday, M. Saadawy, Corros. Sci. 48 (2006) 2765.

5. S. Rajendran, V. Ganga Sri, J. Arockia Selvi, A.J. Amalraj, Bull. Electrochem. 21 (2005) 367.

6. A. Minhaj, P.A. Saini, M.A. Quaraishi, Corros. Preven. Contr. 46 (1999) 32.

7. M. Kliskic, J. Rado Sevic, S. Gudic and V. Katalinic, J. Applied Electrochem. 30 (2000) 823.

8. G. Gunasekaran and L.R. Chauhan, Electrochimica Acta 49 (2004) 4387.

9. A.Y.E. Etre, M. Abdullah, Z.E.E. Tantawy, Corros. Sci. 47 (2005) 385.

10. A. Chetouani, B. Hammouti, Bull. Electrochem. 19 (2003) 23.

11. S. Rajendran, S. Shanmugapriya, T. Rajalakshmi, A. John Amalraj, Corrosion 61 (2005) 685.

12. S. Rajendran, S. Muthulakshmi, R. Rajeshwari, A. Vijitha, J. Electrochem. Soc. 54 (2005) 50.

13. G.O. Avwiri, F.O. Igho, Mater. Lett. 57 (2003) 3705.

14. P.C. Okafor, E.E. Ebenso, Pig. Resin. Tech. 36 (2007) 134.

15. E.E. Oguzie, Pig. Resin. Tech. 35 (2006) 334.

16. K. Anuradha, R. Vimala, B. Narayanasamy, J. Arockia Selvi, S. Rajendran, Chem. Eng. Comm. 195 (2008) 352.

17. G. Wranglen, Introduction to Corrosion and Protection of Metals (London, U.K: Chapman and Hall, 1985) 236.

18. S. Rajendran, B.V. Apparao and N. Palaniswamy, Bulletin of Electrochemistry 13 (1997) 441.

19. T.J. Mabry, H. Wyler, G. Sassu, M. Mercieer, J. Parish and A.S. Dreiding, Helv. Chim. Acta 45 (1962) 640.

20. R.M. Silverstein, G.C. Bassler, T.C. Morrill, Spectrometric Identification of Organic Compounds, John Wiley \& Sons, New York, 1986. p. 95.

21. Y. Sekine Hirakawa, Corrosion 42 (1986) 272.

22. A.J. Amalraj, M.S. Vadivelu, A.P.P. Regis, S. Rajendran, Bull. Electrochem. 17, 4 (2001) 179. 